\title{
FUEL CELLS VS. RENEWABLE ENERGY SOURCES AS DISTRIBUTED GENERATION
}

\author{
H.A.Khattab $^{1} \quad$ M.F.Awad-alla ${ }^{2} \quad$ S.M.Allam $^{1} \quad$ S.M.farrag $^{1}$ \\ ${ }^{1}$ Electrical Engineering Department, Faculty of Engineering, Shebin El-Kom, \\ Minoufiya University, Egypt \\ ${ }^{2}$ Operational Engineer in West Delta Electricity Generation Company, Behera, Egypt
}

\begin{abstract}
DGs are small scale generation sources which are located as near as possible at center of loads. Nowadays, these DGs are becoming more prominent in distribution systems due to the incremental demands of electrical energy and to reduce the power disruption in the power system network. Fuel cells (FCs) are new types of DGs which have numerous benefits that make them superior compared to the other types of DGs. This paper presents a deep review of FCs technology, (definition, structure and theory of work). A general description of FC types is explained, indicating advantages and disadvantages of each type and pointing out their principal use. Finally, economics of producing electricity from different types of FCs, wind and solar energy are examined under different conditions.

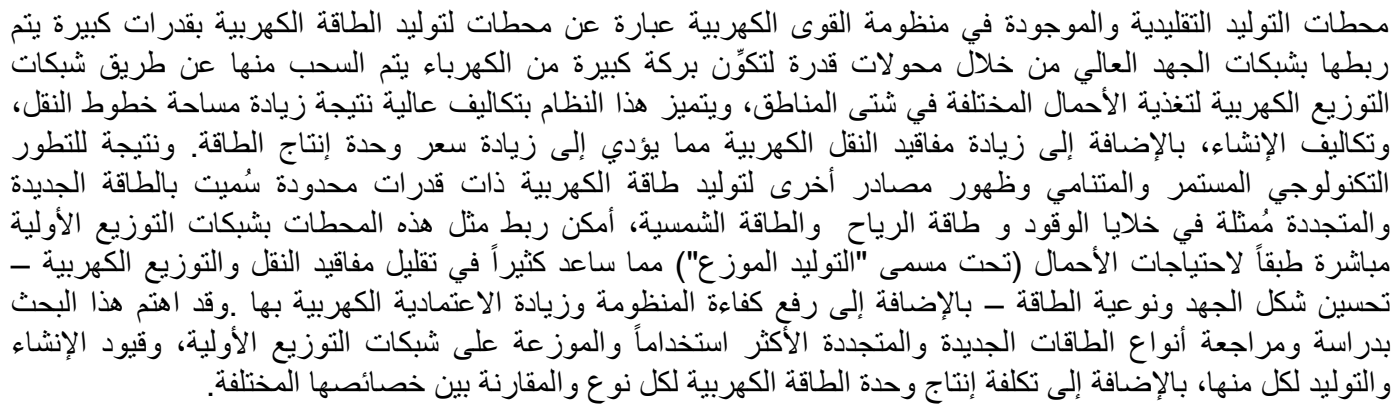

Key words: Fuel cells, Renewable energy, Distributed generation, Unit Energy Cost

\section{1- INTRODUCTION}

Electrical power systems have been traditionally designed taking energy from high voltage levels and distributing it to lower voltage level networks. There are large generation units connected to transmission networks. This current worldwide electric power production is based on a grid-dependent network structure. This system has many disadvantages such as high emissions, transmission losses and large \& long financing requirements. Due to worldwide efforts to reduce the foregoing disadvantages as well as the liberalization of the energy markets, small power stations using new and renewable energy sources are directly connected on primary distribution networks which are called distributed generation (DG). The implementation of DGs have the following advantages: line loss reduction, voltage profile improvements, power quality improvements, low cost, reduction of peak power requirements, increased electric system reliability, increased efficiency levels and reduced environmental impacts [1].

Wind turbine (WT) generators, photovoltaic (PV) cells, micro turbines (MTs), gas turbines (GTs) and FCs are different types of sources which are used mostly in DGs [2]. FCs have a lot of advantages such as high efficiency $35 \%-60 \%$ which can be reach to $80 \%$ in case of "cogeneration", zero emissions, quiet operation, high reliability, quick installation, and the ability to be placed at any site in a distribution system without geographic limitations $[3,4]$.

FCs are used in transportation applications include FC electric vehicles and auxiliary power units for highway, portable applications such as laptop computers and mobile phones, and stationary applications as DG sources.

This paper presents the FC types; definition, structure and theory of work as well as the economics of producing electricity from FCs compared with that produced from wind and solar. 


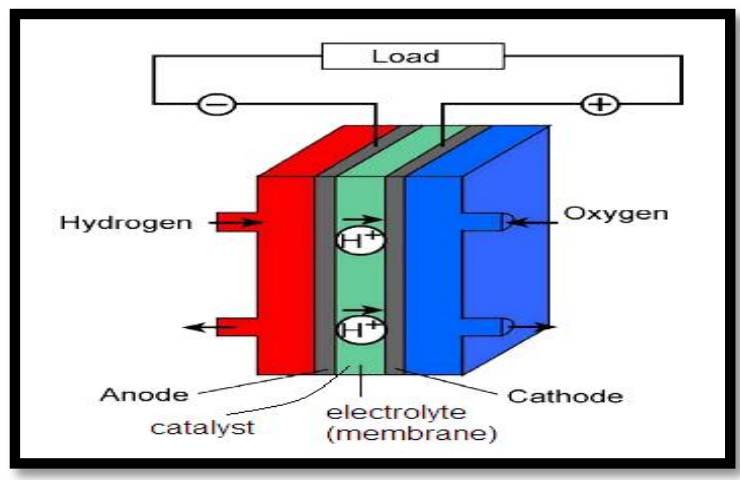

Figure1.Fuel cell construction

\section{2- Structure and work of Fuel Cell}

FC is a device which produces thermal and electrical energy by direct chemical conversion of fuels. Hydrogen is the basic fuel in FCs. Every FC has two electrodes, one positive (anode) and the other negative (cathode). Every FC also has an electrolyte (membrane), which carries electrically charged particles from one electrode to the other, and a catalyst such as platinum, which speeds the reactions at the electrodes. The reactions that produce electricity take place at the electrodes. Water is produced as a waste product.Figure1 shows the basic FC construction $[5,6,7]$.

The Hydrogen atoms are divided into electrons and protons, Protons cross through electrolyte which separate anode to cathode and the movement of electrons generates electricity. These equations show the reaction in a FC (using hydrogen as a fuel).

$\mathrm{H}_{2} \rightarrow 2 \mathrm{H}^{+}+2 \mathrm{e}^{-}$

$4 \mathrm{H}^{+}+4 \mathrm{e}^{-}+\mathrm{O}_{2} \rightarrow 2 \mathrm{H}_{2} \mathrm{O}$

\section{Types of fuel cell}

FCs are divided into several types according to operation temperature and materials. Different types are Polymer electrolyte membrane fuel cell (PEMFC), Alkaline fuel cell (AFC), Phosphoric aside fuel cell (PAFC), Solid oxide fuel cell (SOFC), Molten carbonate fuel cells (MCFCs), Direct methanol fuel cells (DMFCs). Possible fuels are (bio) gas, kerosene products, hydrogen and alcohol. Table 1 shows the comparison of different types of FC $[5,8,9]$.

The last period FC is rabidly increased according to; FC type (Electrolyte), region, and application. Figure 2 shows the development of annual production of FC types [10].

\section{Unit Energy Cost of New and Ren-ewable Energy Sources}

This session presents the economic evaluation when using FC compared with using WT or PV.

\subsection{Fuel cell}

The cost of electricity (COE) is depending on the capital cost, fuel cost, and operation \& maintenance costs. The cost of electricity $(\$ / M W h)$ can be calculated by equation (1) $[6,11]$.

$\mathrm{COE}=(0.125 \mathrm{CC}) / \mathrm{H}+(3.412 \mathrm{~F}) / \varepsilon+(\mathrm{O} \& M) / H$

Where CC, capital cost of the construction $(\$ / \mathrm{kW}) . \mathrm{F}$, fuel cost (\$/MBtu). $\varepsilon$, fractional efficiency. $\mathrm{H}$, annual operating hours divided by 1000 and O\&M, total yearly operating and maintenance cost.

Table 2 shows the CC, O\&M, and COE; where CC and O\&M are given in references [12,13,14,15]. Using equation (1), the COE can be calculated for different type of FCs.

\subsection{Renewable energy}

The most common used from renewable energy sources are wind and solar energy. The worst disadvantage of renewable energy is that their depending on weather conditions.

\subsubsection{Wind energy}

Power in the wind is proportional to the cube of the wind speed. One expression that is often used to calculate the energy from WT is the following [16].

$\mathrm{P}_{\mathrm{w}}=\frac{1}{2} \rho * \mathrm{~A}^{*} \mathrm{v}^{3}$

$\mathrm{E}=\mathrm{P}_{\mathrm{w}} * \mathrm{hr}$

$\left(\mathrm{V} / \mathrm{V}_{0}\right)=\left(\mathrm{H} / \mathrm{H}_{0}\right)^{\wedge} \alpha$

Where $\mathrm{P}_{\mathrm{w}}$, power in wind energy $(\mathrm{kW}) . \rho$, air density $\left(\mathrm{kg} / \mathrm{m}^{3}\right)$. A, cross-sectional area through which the wind passes $\left(\mathrm{m}^{2}\right)$. E, energy of wind turbine. $V$, wind speed at height $(\mathrm{H})(\mathrm{m} / \mathrm{s}) . \mathrm{V}_{0}$, wind speed at height $\mathrm{H}_{0}$. $\alpha$, friction coefficient (from 0.1 to 0.4 ). $\mathrm{v}_{\mathrm{ci}}$ is the cut-in speed and $\mathrm{v}_{\mathrm{co}}$, cut-out speed.

Total annual cost $(\mathrm{TAC})=$ annual capital cost $(\mathrm{ACC})$ + annual operation cost (AOC)

$\mathrm{ACC}=\mathrm{D} . \mathrm{R} * \mathrm{CC}$

Discount rate $(D . R)=\left(r *(1+r)^{\wedge} n\right) /\left((1+r)^{\wedge} n-\right.$ 1)

Where n, number of year (life time) and r, interest rate.

Calculate Unit energy cost in wind \& solar energy by the following formula.

Unit energy cost $(\mathrm{UEC})=(\mathrm{TAC}) /\left(\left.\mathrm{E}\right|_{\text {year }}\right)$

The above equation is used to calculate UEC in Alexandria and the result are shown in table 3 . Magnitude of the mean wind speed in Alexandria is $4.6(\mathrm{~m} / \mathrm{s})$ at height $10 \mathrm{~m}[17]$.

\subsubsection{Solar energy}

One of application of solar energy is photo-voltaic, (PV). PV absorbs solar energy from the sunlight and converts it to dc electricity. The energy delivered from solar plants is as following [17].

$\left.\mathrm{E}\right|_{\text {Day }}=\mathrm{H} * \mathrm{~A} * \xi$ 
$\left.\mathrm{E}\right|_{\text {Year }}=\mathrm{E} * 365$

Where $\left.\mathrm{E}\right|_{\text {Day }}$, energy delivered in a day $(\mathrm{kwh}) .\left.\mathrm{E}\right|_{\text {Year }}$ ,energy delivered in a year (kwh). A, area of the PV array $\left(\mathrm{m}^{2}\right)$. H, magnitude of the average solar radiance every day $\left(\mathrm{kwh} / \mathrm{m}^{2}\right)$ and $\xi$, average system efficiency over the day.

The above equations are used to calculate UEC from $\mathrm{PV}$ in Alexandria and the results are shown in table 4. Magnitude of the average solar radiance is $\left(5\left(\mathrm{kwh} / \mathrm{m}^{2}\right) /\right.$ day $)[18]$.
According to the foregoing results, we can evaluate the cost of electrical energy given from FC, wind energy and PV. Although electric energy produced by FC doesn't the cheapest, however, it enables us to operate in any place at any time without depending on weather conditions and doesn't need a large land area and operates as near as possible at center of loads.

Table 1 Comparison of different types of FC

\begin{tabular}{|c|c|c|c|c|c|c|}
\hline \multirow{2}{*}{ Parameters } & \multicolumn{6}{|c|}{ FC types } \\
\hline & $P E M F C$ & $A \boldsymbol{F} C$ & $P A F C$ & MCFC & SOFC & $D M F C$ \\
\hline Electrolyte & $\begin{array}{c}\text { Solid } \\
\text { polymer } \\
\text { membrane }\end{array}$ & $\begin{array}{c}\text { Liquid } \\
\text { solution } \\
\text { such as } \\
\text { potassium } \\
\text { hydroxide }\end{array}$ & $\begin{array}{c}\text { Phosphoric } \\
\text { acid }\end{array}$ & $\begin{array}{c}\text { molten } \\
\text { carbonate } \\
\text { or } \\
\text { potassium } \\
\text { carbonate }\end{array}$ & $\begin{array}{l}\text { solid ceramic } \\
\text { material }\end{array}$ & $\begin{array}{c}\text { Solid } \\
\text { polymer } \\
\text { membrane }\end{array}$ \\
\hline $\begin{array}{c}\text { Result } \\
\text { temperature }\end{array}$ & $50-100^{\circ} \mathrm{C}$ & $50-200^{\circ} \mathrm{C}$ & $\sim 200^{\circ} \mathrm{C}$ & $\sim 650^{\circ} \mathrm{C}$ & $800-1000^{\circ} \mathrm{C}$ & $60-200^{\circ} \mathrm{C}$ \\
\hline Efficiency & $40-50 \%$ & $\sim 50 \%$ & $40 \%$ & $50 \%$ & $50 \%$ & $40 \%$ \\
\hline $\begin{array}{c}\text { Application } \\
\text { Used in: }\end{array}$ & $\begin{array}{l}\text { - Vehicles } \\
\text { Residential } \\
\text { application }\end{array}$ & $\begin{array}{l}\text { - Transport } \\
\text { - space } \\
\text { shuttles } \\
\text { - portable } \\
\text { power } \\
\end{array}$ & $\begin{array}{l}\text { - Transport } \\
\text { - commercial } \\
\text { cogeneration } \\
\text { - portable } \\
\text { power } \\
\end{array}$ & $\begin{array}{c}\text { - Transport } \\
\text { - industrial } \\
\text { - utility } \\
\text { power } \\
\text { plant }\end{array}$ & $\begin{array}{l}\text { - Residential } \\
\text { - Stationary\& } \\
\text { portable } \\
\text { power plants }\end{array}$ & $\begin{array}{l}\text { - portable } \\
\text { devices } \\
\text { - Vehicles } \\
\text { application }\end{array}$ \\
\hline Advantage & $\begin{array}{c}\text {-High } \\
\text { power } \\
\text { density } \\
\text {-Low } \\
\text { corrosion } \\
\text {-Lower } \\
\text { operating } \\
\text { temperatur } \\
\text { e } \\
\text {-Long life } \\
\text { time } \\
\end{array}$ & $\begin{array}{c}\text { - High power } \\
\text { density } \\
\text { - Lower } \\
\text { operation } \\
\text { temperature }\end{array}$ & $\begin{array}{c}\text { - stable } \\
\text { electrolyte } \\
\text { characteris- } \\
\text { tics } \\
\text { - use impure } \\
\text { fuel }\end{array}$ & $\begin{array}{l}\text { - High } \\
\text { efficiency } \\
\text { - Catalyst } \\
\text { Cheap }\end{array}$ & $\begin{array}{l}\text { - Solid } \\
\text { electrolyte } \\
\text { - High } \\
\text { efficiency } \\
\text { generate high } \\
\text { grade waste } \\
\text { heat } \\
\text { - Low } \\
\text { corrosion }\end{array}$ & $\begin{array}{l}\text { - Reduced } \\
\text { cost due to } \\
\text { absence of } \\
\text { fuel } \\
\text { reformer } \\
\text { (use liquid } \\
\text { methanol } \\
\text { as fuel) }\end{array}$ \\
\hline Drawbacks & $\begin{array}{l}\text { - a cost of } \\
\text { platinum } \\
\text { electrolyte }\end{array}$ & $\begin{array}{c}\text { - Expensive } \\
\text { platinum } \\
\text { catalyst } \\
\text { - use very } \\
\text { pure } \\
\text { hydrogen }\end{array}$ & $\begin{array}{c}\text { - Corrosive } \\
\text { liquid } \\
\text { electrolyte } \\
\text { - expensive } \\
\text { catalyst } \\
\text { - Low } \\
\text { current }\end{array}$ & $\begin{array}{c}\text { - High cost } \\
\text { - Corrosive } \\
\text { liquid } \\
\text { electrolyte } \\
\text { - short life } \\
\text { time }\end{array}$ & $\begin{array}{l}\text { - High cost } \\
\text { - increase } \\
\text { friction and } \\
\text { speed up the } \\
\text { breakdown } \\
\text { - short life } \\
\text { time }\end{array}$ & $\begin{array}{l}\text { - Lower } \\
\text { efficiency } \\
\text { and power } \\
\text { density }\end{array}$ \\
\hline
\end{tabular}

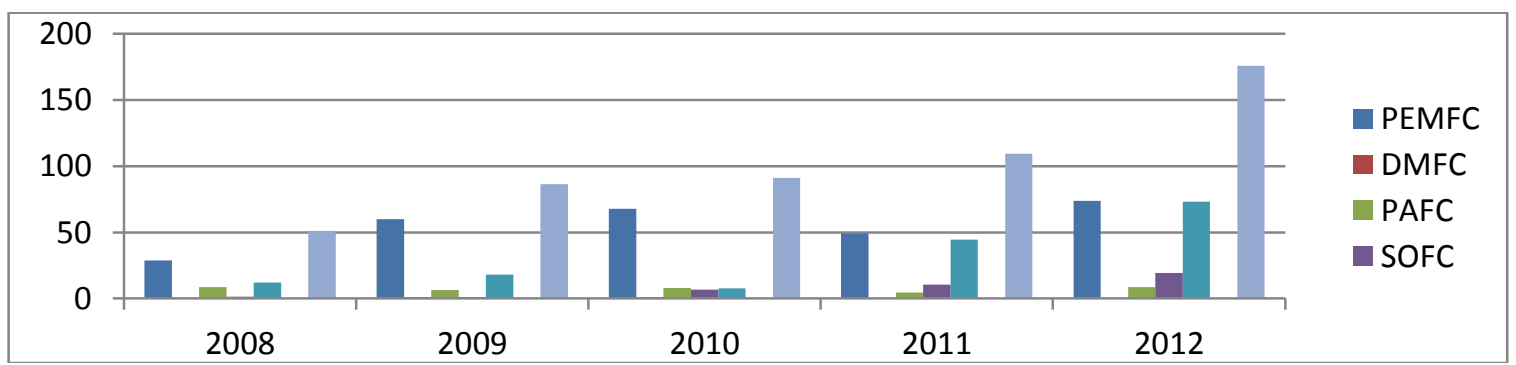

Figure 2. The development of annual production of FC types 
Table 2. The cost of MCFC \& PAFC

\begin{tabular}{|c|c|c|c|c|c|c|}
\hline type & \multicolumn{3}{|c|}{ MCFC } & \multicolumn{2}{c|}{$\boldsymbol{P A F C}$} \\
\hline power & \multicolumn{2}{|c|}{$\mathbf{2 5 0} \mathbf{k W}$} & $\mathbf{1 . 4} \mathbf{M W}$ & $\mathbf{5 * 2 0 0 ~} \mathbf{k W}$ & \multicolumn{2}{c|}{$\mathbf{5}^{* 200} \mathbf{k W}$} \\
\hline Year & Before 2003 & $7-2003$ & 2010 & 2011 & 2007 & 2011 \\
\hline $\boldsymbol{C C} \mathbf{( \$ / k W )}$ & 9600 & 5800 & 4200 & 3000 & 5500 & 3000 \\
\hline $\boldsymbol{O \& M}$ & 347 & 400 & 317.85 & 317.85 & 457.4 & 457.4 \\
\hline $\boldsymbol{C O E}(\boldsymbol{\phi} / \mathbf{k W h})$ & 28.88 & 14.7 & 17.79 & 15.9203 & 19.28 & 18.42 \\
\hline
\end{tabular}

Table 3 The characteristics and comparison between different types of wind turbines.

\begin{tabular}{|c|c|c|c|}
\hline Rated power,,$(\boldsymbol{k W})$ & $\mathbf{8 5 0}$ & $\mathbf{1 0 0 0}$ & $\mathbf{1 5 0 0}$ \\
\hline $\boldsymbol{v}(\boldsymbol{m} / \mathbf{s})$ & 5.334615 & 5.403247 & 5.4745 \\
\hline $\boldsymbol{U E C}(\boldsymbol{\phi} / \mathbf{k W h r})$ & 18.67 & 16.003 & 12.01 \\
\hline
\end{tabular}

Table 4 The cost of different types of solar energy.

\begin{tabular}{|c|c|c|c|}
\hline Rated power & $\mathbf{1 7 5}$ W power / unit & 225 W power / unit & 1000W power / unit \\
\hline $\boldsymbol{C C}(\mathbf{\$} / \mathbf{k W})$ & $4.157858^{*} 10^{\wedge} 3$ & $4.157858 * 10^{\wedge} 3$ & $1 * 10^{\wedge} 3$ \\
\hline $\boldsymbol{U} \boldsymbol{E} \boldsymbol{C}(\boldsymbol{\phi} / \mathbf{k W h})$ & 40.35 & 40.3 & 21.52 \\
\hline
\end{tabular}

\section{5- Conclusions}

- WT generators, PV cells, MTs, GTs and FCs are different types of DG sources, and the most common used are WT, PV, and FCs.

- Although electric energy produced by FC doesn't the cheapest, however, it can be operated in any place at any time without depending on weather conditions.

- FCs have many advantages over other power distributed generation such as high efficiency, low emissions, more flexibility, high reliability, low maintenance, and multi-fuel capability.

- Because of their efficiency and environmental advantages, FC technologies are viewed as an attractive solution to energy problems. As the demand is high, several different types of FCs are suitable for applications in the commercial market and will compete with one another.

- Also, FC has the capability of providing both heat and electrical power. The overall efficiency of a cogeneration system can be increased up to80\%.

- FCs can be stacked together to meet required power demand, from a few watts to megawatts. FC produces electricity at competitive rates especially for large ratings.

\section{References}

[1] Athira Jayavarma, Tibin Joseph et al., "Optimal Placement of Fuel Cell DG and Solar PV in Distribution System using Particle Swarm Optimization,"International Journal of Scientific \& Engineering Research, Volume 4, Issue 9, September-2013

[2] EG\&G Technical Services, Inc., "Fuel Cell Handbook (Seventh Edition),", U.S. Department of Energy Office of Fossil Energy National Energy Technology Laboratory, November 2004
[3] Leonardo Giorgi and Fabio Leccese, "Fuel Cells Technologies and Applications," The Open Fuel Cells Journal, 1-20, 6, 2013

[4] Brian Cook, "AN INTRODUCTION TO FUEL CELLS AND HYDROGEN TECHNOLOGY," Heliocentris, Canada, December 2001

[5] A. kirubakaran et al., "A review on fuel cell technologies and power electronic interface," renewable and sustainable energy reviews 13 , 2430-2440, 2009

[6] Alin C. Fărcaş, Petru Dobra,"Adaptive control of membrane conductivity of PEM fuel cell," Procedia Technology 12, 42 - 49, 2014

[7] Chris Rayment \& Scott Sherwin, "Introduction to Fuel Cell Technology," Department of Aerospace and Mechanical Engineering University of Notre Dame, U.S.A., May 2, 2003.

[8] Staff of the Breakthrough Technologies Institute, Inc., in Washington, DC., 2011 "2011 FUELCELL TECHNOLOGIES, MARKET REPORT," U.S DEPARTEMENT OF Energy, July 2012

[9] http://www.fuelcelltoday.com/about-fuelcells/case studies/technology-types

[10]Johnson Matthey, "The Fuel Cell Today Industry Review 2013," fuel cell today, September 2013

[11] Timothy Lipman, Jennifer L. Edwards, "FUEL CELL SYSTEM ECONOMICS: COMPARING THE COSTS OF GENERATING POWER WITH STATIONARY AND MOTOR VEHICLE PEM FUEL CELL SYSTEMS," Energy Policy 32, 101-125, 2004

[12]D. Rastler, "Case Studies of $250-\mathrm{kW}$ Carbonate Fuel Cells," EPRI, March 2005

[13]D. Thimsen, "Case Study of 250-kW Molten Carbonate Fuel Cell,", March 2004. 
[14] Douglas Wheeler, "Molten Carbonate and Phosphoric Acid Stationary Fuel Cells: Overview and Gap Analysis," National Renewable Energy Laboratory, September 2010

[15]E. Torrero, M. Binder, "1 MW Fuel Cell Project," EPRI, July 2002

[16] Gilbert M. Masters, "Renewable and Efficient Electric Power Systems," Published by John
Wiley \& Sons, Inc., Hoboken, New Jersey, Stanford University, 2004

[17] Niels G. Mortensen1, Jens Carsten Hansen et al., "WIND ATLAS FOR EGYPT: MEASUREMENTS,MICRO-

ANDMESOSCALEMODELLING," Wind Energy Department, Risø National Laboratory, Roskilde, Denmark

[18] http://www.abb.com/search.aspx?q=vol.10 